\title{
CRITICALLITY OF TRANSPORTATION INFRASTRUCTURE IN CZECH REPUBLIC
}

\author{
Jan ProcházKa*, DANa Procházková \\ Czech Technical University in Prague, Faculty of Transportation Sciences, Praha, Czech Republic \\ * corresponding author: prochazka@fd.cvut.cz
}

\begin{abstract}
The paper deals with transportation infrastructure criticality because this quantity determines the State capability to overcome the critical conditions and to ensure the inhabitants survival. The criticality rates for individual types of transportation infrastructure and for the entire transportation infrastructure are determined by data from experts from the areas: transportation; transportation management in the territory; supply chains; public administration; and the Integrated Rescue System. The experts assessed 14 factors, which have been often used in the developed world countries, from the view of human security and development. The result values and their interpretations were determined by using the Multiatribute Utility Theory.
\end{abstract}

KEYWORDS: transportation infrastructure, system of systems, interdependences, criticality, interoperability, serviceability, human survival, State stability.

\section{INTRODUCTION}

Transportation infrastructure belongs to the basic systems that make up the critical infrastructure in the European Union, in developed countries and also in the Czech Republic. We understand the system of transportation in accordance with the current knowledge as a system of systems, i.e. the set of several overlapping systems. The most important property in such type of system is the interoperability of partial systems that depends on interdependences [1]. The interdependences are the cause of different emergent phenomena and cascade failures that cause that the transportation infrastructure does not fulfil its function, i.e. the serviceability of territory at normal, abnormal and critical conditions if it is threatened the human survival and State stability. Therefore, it is necessary to manage the transportation infrastructure by the way so infrastructure criticality is acceptable [1].

The subject of this work is to assess the criticality of the transportation infrastructure in the Czech Republic on the basis of the integral safety concept, which aims are security and development of the territory concerned and its inhabitants. The concept used is based on the knowledge of the reality of the dynamic development of the human system and it considers that human system conditions are normal, abnormal and critical. The capability to overcome the critical conditions, ensuring the survival of humans and to have capability to stabilize the situation we consider crucial, and therefore, we use the degrees of criticality, which are aimed at assessing the aspects associated with the given properties. For the assessment of the criticality we use criteria used in developed countries, multi-objective approach and data from experts whose qualification is certified according to the criteria used in the European Union [1].

\section{Current Knowledge on TrANSPORTATION INFRASTRUCTURE}

The transportation system, which provides transportation of humans and goods, includes all modes of transportation, which, under the coordination of individual transportation systems work together and create a logistical network [2]. Transportation logistics network is currently becoming a very important area of business activities, and not just in a regional and national scale, but also in international relations. The transportation network can be combined with energy as one of the foundations of the economic prosperity of States and organizations.

Transportation systems for their activities require a considerable amount of funds, namely in investment, operational and administrative domains, which typically create autonomous sub-sectors, the activity of which is mutually coordinated. The characteristic feature of those technological units is their capability to own separate activity, and therefore, they are often considered as closed units, which is projected to the safety concept, and at risk management it is used the simplest approach, i.e. the procedures for a closed system, in which the sources of the risk are only the technical problems and the human factor 2 .

Infrastructure of transportation network is currently mostly owned by the public sector; however, its development is largely determined by the requirements of private sector. Simultaneously it constitutes an important element of the economy and of the citizens living way. Transportation network has considerable international political influence, as it allows the international cooperation of individual States and tourism, which contributes to the integration of citizens.

The transportation system is built from the separate parts that make up certain units that provide certain 
circuit activities separately. In the serviceability of territory (creating the space for human lives, i.e. the human system), however, the units are together overlapped, i.e. they create a system of systems [2] [3] [4. The ground of each unit is a specific type of transportation vehicles, accompanied by complex of operational and administrative procedures. The characteristic feature of these technological units is their specialized capability to separate operation, i.e. the autonomy. The capability to separate operation, however, it is only apparent, the sub units are bound by the rules of their transport logistics, which not only coordinates their activities, but also makes it economically more profitable because it reduces operating costs. On the other hand, however, it is the source of internal dependencies "interdependences" [2] [5]. Safety of transportation networks in the past was provided only by a simple guarding. The guarding was mostly limited to surveillance, which should prevent the mostly property-related offences, such e.g. theft of the goods transported, pertinently endangering the personal safety of transported passengers. On the basis of current knowledge, it is the aim of the safety management of the transportation system, which consists of objects and infrastructures, ensuring the security and development of both, the transportation system and transportation system vicinity, because it is the only way how to ensure the safe human system. On the basis of current knowledge, this means that we have to apply the tools of the disciplines that provide safety management of complex systems [1] [2] [5]; i.e. the multi criterial approach based on expert assessment of the possible variants that describe the behaviour of systems of systems designated by different behaviour of individual subsystems [4].

\section{Transportation System of the Czech Republic}

In the Czech Republic a transportation network is in essence created from the following areas: railway transport system; road transport system; air transport; and water transport. The main activities of the business in the transport are passenger and freight transport. Ensuring the rational operation requires considerable resources - labour, capital, information, as in a modern industrialized society, it is common that the interconnection and operation of transportation networks and the provision of transport services is an important part of near all other activities. For example, the provision of transport services in the major cities is done by public transportation, which is based on mostly coordinated cooperation of road and rail transport, sometimes supplemented by underground transportation; it is basically so called integrated transportation system. In the last few decades, the transportation infrastructure has become a major target of terrorist attacks. In particular, it clearly reflected in the air transport, in which they terrorists originally focused only on the kidnappings, and the destruction of the aircraft in flight [5]. After the attacks of 11 September, 2001 on the Trade Centre in New York, it turned out that the aircraft may change in the gun with the devastating consequences of the disastrous. From historical practice it is known that natural disasters (in our condition floods, storms, earthquakes and landslides) often caused considerable and practically difficult to quantify damages to parts of the rail and road transport of technological system and the environment. Therefore, it can be concluded that transportation systems are particularly vulnerable to attacks and natural disasters. They are very favourite target of the activities of terrorists who by attack on any of transportation systems can cause considerable damage to property and infrastructure devices. It is necessary to recognize that the indirect impacts of attacks and their consequences can even endanger the stability of the economics of the industry, or even the State. From the above analysis it follows that it is necessary to devote to the issue of the destruction of the infrastructure of transportation systems special attention, to define particularly sensitive parts and to search for ways how to reduce the danger of the destruction of important parts, which can cause the interruption of the activity of transportation systems, and by such way to prevent the economic destabilization not only of the relevant business units, but also to other bodies in the industrial areas. If we want to manage the transportation system safety with the aim of ensuring its security and development, so we need to know the priority aspects, on which the achievement of objectives depend and on that we need to focus the attention, i.e. the measures and activities [1] [5]. From the same source it follows that the critical spots in the technological system (object, the infrastructure, plant, facility, territory) are the places where the basic technological processes are under way and for which there are in force specific provisions for the safety under normal, abnormal and critical conditions (e.g. single-level crossing of the railways and roads in the village). Table 1 gives the important parts of the transportation system, separated for four of its parts according to criteria of Governmental decree No. 2000 Col. 6.

\section{Method for Determining the TRANSPORTATION INFRASTRUCTURE CRITICALITy}

According to the detailed discussion given in [1] [5] the criticality of item means that item has simultaneouslygreat importance and great vulnerability. It means that we work with conflict criteria at the solution of problem. Therefore, we use the strategy defined by the Keeny and Raiffa [7] defined by the mathematical statement "the higher, the worse, i.e. the higher criticality in our case".

As it has been already said above, the transportation system as a whole and its basic subsystems are 


\begin{tabular}{|c|c|c|c|c|}
\hline & Rail transport & $\begin{array}{l}\text { Road trans- } \\
\text { port }\end{array}$ & Air transport & $\begin{array}{l}\text { Water trans- } \\
\text { port }\end{array}$ \\
\hline $\begin{array}{l}\text { Linear } \\
\text { construc- } \\
\text { tions }\end{array}$ & $\begin{array}{l}\text { Tracked rail network, } \\
\text { The electrification net- } \\
\text { work of railways, Rail- } \\
\text { way security network }\end{array}$ & $\begin{array}{l}\text { The full road net- } \\
\text { work }\end{array}$ & $\begin{array}{l}\text { The system of inter- } \\
\text { connected airports }\end{array}$ & The waterways \\
\hline Objects & $\begin{array}{l}\text { The railway station } \\
\text { buildings for traffic } \\
\text { management, expe- } \\
\text { dition of passengers } \\
\text { and redeployment of } \\
\text { goods, The depots } \\
\text { of vehicles, Railway } \\
\text { workrooms, Railway } \\
\text { bridges, Railway } \\
\text { tunnels, Track Divi- } \\
\text { sionmaintenance rail } \\
\text { network objects and } \\
\text { networks for security } \\
\text { techniques, Railway } \\
\text { workrooms for servic- } \\
\text { ing the locomotives } \\
\text { of all kinds and fleet, } \\
\text { The power stations of } \\
\text { power supply to rail } \\
\text { network, Fuel stations }\end{array}$ & $\begin{array}{l}\text { Road bridges, } \\
\text { Road tunnels, } \\
\text { Stocks of fuels } \\
\text { for road trans- } \\
\text { port purposes, } \\
\text { Objects for the } \\
\text { management of } \\
\text { road traffic, Gas } \\
\text { fuel stations for } \\
\text { road vehicles, } \\
\text { Objects for the } \\
\text { management } \\
\text { of emergency } \\
\text { situations in } \\
\text { road network }\end{array}$ & $\begin{array}{l}\text { Airport runways for } \\
\text { takeoff and landing, a } \\
\text { network of runways, } \\
\text { lighting, Passing ways, } \\
\text { Aircraft stands, Build- } \\
\text { ings for service sta- } \\
\text { tions for air transport, } \\
\text { Buildings for normal } \\
\text { preflight preparation- } \\
\text { input and general ex- } \\
\text { amination, Air traf- } \\
\text { fic control objectsair- } \\
\text { port, regional, The } \\
\text { radar station for air } \\
\text { traffic control, Radar } \\
\text { stations for meteorol- } \\
\text { ogy, Computing Cen- } \\
\text { tre of the airport, } \\
\text { The equipment for op- } \\
\text { erational information } \\
\text { sharing for regional } \\
\text { service, Facilities for } \\
\text { the sharing of opera- } \\
\text { tional information for } \\
\text { the management of the } \\
\text { activities of the air- } \\
\text { port, Centre for inter- } \\
\text { vention in emergency } \\
\text { traffic incidents (acci- } \\
\text { dents...), Gas stations } \\
\text { and fuel warehouse }\end{array}$ & $\begin{array}{l}\text { Ports with the } \\
\text { devices, The } \\
\text { locks, Docks, Hy- } \\
\text { drometeorology } \\
\text { stations, objects } \\
\text { for maintenance } \\
\text { of vessels, Fuel } \\
\text { stations }\end{array}$ \\
\hline Fittings & $\begin{array}{l}\text { Rail vehiclesloco- } \\
\text { motives and cars, } \\
\text { Equipment of the } \\
\text { rail stations and the } \\
\text { tracked rail network, } \\
\text { Device for controlling } \\
\text { the places on the } \\
\text { crossing the road and } \\
\text { rail transport, The } \\
\text { equipment for oper- } \\
\text { ational information } \\
\text { sharing within the } \\
\text { operation of the rail } \\
\text { system, Facilities for } \\
\text { the supply of fuel for } \\
\text { vehicles }\end{array}$ & $\begin{array}{l}\text { The equipment } \\
\text { for operational } \\
\text { information shar- } \\
\text { ing with the road } \\
\text { network, Equip- } \\
\text { ment of centres } \\
\text { with technique } \\
\text { for solving in- } \\
\text { cidents, Buses, } \\
\text { Freight cars, Per- } \\
\text { sonal cars }\end{array}$ & Aircrafts & Ships \\
\hline
\end{tabular}

TABLE 1. Important parts of transport system 
systems of systems, i.e. it goes on several mutually penetrating systems of different nature (technical, organizational, financial, human resources, and legal), and therefore, the criticality assessment cannot be performed from a single indicator, but it is necessary to use a multicriterial approach and information from experts [4. In accordance with the procedures that are used in the USA, Australia, Canada etc. [8 [9 [10 11 [12 13 there were used the following factors important to the criticality of transportation infrastructure:

- a rate of capability of defence,

- a rate of vulnerability to attack,

- a rate of threat to the health and lives of humans,

- a rate of accidents impact on the environment

- a rate of cost of exchange or repair,

- a rate of exchange time or repair time,

- a rate of importance for ensuring the life-saving or emergency functions in the territory,

- a rate of importance for ensuring the functions of administration and local government,

- a rate of importance for ensuring the functions of army and police,

- a rate of redundancy or replacement services,

- a rate of importance for ensuring the communication functions,

- a rate of impact of frontage failure on the economy of region (State),

- a rate of importance of operability,

- a rate of importance in the field of symbolic, cultural, etc.

With the facts in the documentation of the Czech Republic transportation system 14 and with the data from 5 experts, selected according to the criteria of the EU given in [1], from the areas: transportation; transportation management in the territory; supply chains; public administration; and the Integrated Rescue System, there wereobtained verbal assessments of the factors mentioned above. Since the main human objective is the human safety and the human development [3], for which the safe transportation infrastructure is vital, the criticality of the transportation infrastructure is understood from the perspective targeted on the human survival.

Therefore, the verbal assessment was transferred with the help of five experts participating in the Panel discussion into the numerical scale that is analogue to the scale using in the risk assessment in the CSN standards [1] - allocate number of points is the following:

(1.) if factor does not contribute to the criticality of the transport system (the expected damages are less than 5\%),
(2.) if factor contributes little to the criticality of the transport system (damages are expected at an interval of $5-25 \%$ ),

(3.) if factor contributes intermediately to the criticality of the transport system (the expected damages are in the interval $25-45 \%$ ),

(4.) if factor contributes significantly to the criticality of the transport system (the expected damages are in the interval of $45-70 \%$ ),

(5.) if factor contributes very significantly to the criticality of the transport system (the expected damages are in the interval of 70-95\%),

(6.) if factor significantly contributes most significantly to the criticality of the transport system (the expected damage is greater than 95\%).

The resulting evaluation of criticality for each partial system provided that we give equal weight to all factors, can have the values 0 to 70 and for the entire system having 4 subsystems, provided that their equivalence the criticality values are between 0 and 280. If we again apply approach used in the ČSN standards 1], we get the data given in Table 2

\section{Results - the CRitichlity Rates FOR TRANSPORT INFRASTRUCTURE}

The verbal assessments of factors for rail transport, obtained from the experts are the following:

(1.) Rate of capability of defence - defence of the railway is difficult due to the considerable complexity of rail system. At the attack of terrorists on main parts or at natural disaster there may originate extensive damages that stop the operation of a large part of the system. The human factor and organizational accident can also cause considerable damages.

(2.) Rate of vulnerability to attack - vulnerability of the railway is significant because some parts of it can be quite simply destroyed extensively (railway stations complexes, bridges, tunnels, etc.).

(3.) Rate of threat to the health and lives of humans the health and lives of passengers are threatened by practically in all the accidents of the rail system.

(4.) Rate of impact of railway accidents on the environment - railway accidents can have significant impacts on the environment, in particular in the transport of fuels, chemicals and other raw materials. Removal of contamination of environment is the most difficult and expensive.

(5.) Rate of cost of exchange or repair - elimination of damages caused by the destruction of the track system can be mostly done without the big cost. Expensive there are large constructions repairs of faulty bridges and tunnels. Repair or restoration of the destroyed railway vehicles is often expensive. 


\begin{tabular}{||l|l|l|l||}
\hline \multirow{2}{*}{ Criticality rate } & \multicolumn{3}{|c||}{ Score } \\
\cline { 2 - 4 } & $\begin{array}{l}\text { The percentage of } \\
\text { the total value }\end{array}$ & $\begin{array}{l}\text { Individual trans- } \\
\text { port systems }\end{array}$ & $\begin{array}{l}\text { Entire transport } \\
\text { system }\end{array}$ \\
\hline The extremely high & more than 95\% & more than 66.5 & more than 266 \\
\hline Very high & $70-95 \%$ & $49-66.5$ & $196-266$ \\
\hline High & $45-70 \%$ & $31.5-49$ & $126-196$ \\
\hline Medium & $25-45 \%$ & $17.5-31.5$ & $70-126$ \\
\hline Very small & $5-25 \%$ & $3.5-17.5$ & $14-70$ \\
\hline $\begin{array}{l}\text { Insignificant / negligi- } \\
\text { ble }\end{array}$ & less than 5\% & less than 3.5 & less than 14 \\
\hline
\end{tabular}

TABLE 2. Value scale used for determining the criticality rate

(6.) Rate of exchange time or repair time - repair of tracks is quite fast. Large construction repairs of bridges and tunnels require a longer period of time.

(7.) Rate of importance for ensuring the life-saving or emergency functions in the territory - in emergency situations the railway is very important and often essential for the provision of emergency activities.

(8.) Rate of importance for ensuring the functions of administration and local government - for the provision of administrative and self-government the railway is important, but its services for the activities in most cases can be replaced by other means of transport.

(9.) Rate of importance for ensuring the functions of army and police - to the needs of the army and the police the railroad is necessary.

(10.) Rate of redundancy or replacement services backup at the railway is quite high (multiple lines), particularly in the transport of basic industrial raw materials, food, and fuel in larger quantities. Very important it is container shipping service linking the various transport systems and container transport requires its own technology. In particular, the important role has container transport in international traffic, which of course, requires the construction of investment-intensive terminals, which can be a sensitive target for terrorists.

(11.) Rate of importance for ensuring the communication functions - in emergency case, the communication network of railway can be used because it is independent.

(12.) Rate of impact of frontage failure on the economy of region (State) - disturbed rail traffic system adversely affects the smooth running of the regional or national economy and causes considerable economic losses.

(13.) Rate of importance of operability - railway operability is very important on both, the national and the international scales.

(14.) Rate of importance in the field of symbolic, cultural, etc. - .-the level and status of the railway transport system is testimony to the cultural and technical level of the State.
The verbal assessments of factors for road transport, obtained from the experts are the following:

(1.) Rate of capability of defence - protection of the road network is complex because even if the disruption of the custom paths can be quite easily and quickly repair, sensitive parts such as bridges and tunnels it is necessary against terrorist attacks and natural disasters especially consistently to protect, because their damage or destruction often requires a long-term repair, mostly investment-intensive. The human factor and organizational accident can also cause considerable damages.

(2.) Rate of vulnerability to attack - vulnerability of road network is particularly determined by sensitive parts of system, such as bridges, tunnels, etc.

(3.) Rate of threat to the health and lives of humans health and lives are threatened by accidents during the operation, the number of which can be in the effective management of road traffic minimised.

(4.) Rate of impact of road accidents on the environment - road transport heavily polluting environment by gases that vehicles emit into the atmosphere. When accidents of vehicles, environmental pollution is caused in particular by spilling fuel and possibly also by transported goods that is spread in nature.

(5.) Rate of cost of exchange or repair - except the costly repairs of sensitive network places - bridges tunnels etc. it is possible to perform repairs of damages of road network fairly cheaply and in a short time.

(6.) Rate of exchange time or repair time - outside the repairs of bridges, tunnels and other expensive parts it is possible to perform the repairs of network in a relatively short time.

(7.) Rate of importance for ensuring the life-saving or emergency functions in the territory - the serviceability of roads is very important, in the case of an emergency it can be solved by the finding a replacement path that avoids the damaged parts.

(8.) Rate of importance for ensuring the functions of administration and local government - road transport is very necessary. 
(9.) Rate of importance for ensuring the functions of army and police - road transport is fundamentally necessary.

(10.) Rate of redundancy or replacement services there are, in principle, to allow mutual logistic redundancy compensation of individual transport systems.

(11.) Rate of importance for ensuring the communication functions - communication function can be partially replaced by road transport.

(12.) Rate of impact of frontage failure on the economy of region (State) - the status and level of road system quality has a significant influence on the economy.

(13.) Rate of importance of operability - operability of the road system is very important and fundamentally affects all activities in the region and State.

(14.) Rate of importance in the field of symbolic, cultural, etc. - the level of road transport and the road system is indicative of the level of the State and its tradition.

The verbal assessments of factors for air transport, obtained from the experts are the following:

(1.) Rate of capability of defence - defence of air transport is very exacting and difficult, because the air transport system is currently the most complex of all transport systems. The accidents in aviation occur from reasons, the technical reasons and the meteorological reasons. However, the air transport is also a hot target for terrorists. The human factor and organizational accident can also cause considerable damages.

(2.) Rate of vulnerability to attack - the vulnerability is high. Preparation of the aircraft for operation is very challenging. Therefore, the flight and technical staff is carefully selected and trained. Defence against terrorist attacks is performed while the intensely, but not always successfully.

(3.) Rate of threat to the health and lives of humans - in air accidents it is occurred injury and death of crew and passengers. Therefore, the prevention of accidents in the aviation service is very important.

(4.) Rate of impact of road accidents on the environment - air accidents are almost always accompanied by considerable local damage to the environment, but mostly they are hitting a small part of the territory.

(5.) Rate of cost of exchange or repair - replacement of the damaged aircraft technique is almost always very costly financially and time often challenging. Repairs require a considerable supply of spare parts and the repair work of specialists. The repair needs to be carried out at the manufacturers or authorised service companies.
(6.) Rate of exchange time or repair time - the time length of the repair is different according to the nature of the fault.

(7.) Rate of importance for ensuring the life - saving or emergency functions in the territory - aviation equipment has a significant position and it is almost necessary in response to real crisis situations of all kinds.

(8.) Rate of importance for ensuring the functions of administration and local government - it is important only conditionally.

(9.) Rate of importance for ensuring the functions of army and police - it is very necessary.

(10.) Rate of redundancy or replacement services - air transport has a conditional redundancy that from its independence on surface networks enables to solve specific tasks.

(11.) Rate of importance for ensuring the communication functions - in some exceptional cases, air transport is the only viable solution.

(12.) Rate of impact of frontage failure on the economy of region (State) - air transport is of great importance for the economy, because outside of its own air traffic it is driving article of industry.

(13.) Rate of importance of operability - it is very important.

(14.) Rate of importance in the field of symbolic, cultural, etc. - air transport in the Czech Republic has a significant position in the world. The aviation industry of the Czech Republic has a long tradition, the products have been exported into all world.

The verbal assessments of factors for water transport, obtained from the experts are the following:

(1.) Rate of capability of defence - with regard to the limited scope of the network of waterways in the Czech Republic this transport system can be probably successfully protected. The human factor and organizational accident can also cause damages.

(2.) Rate of vulnerability to attack - the vulnerability of the network of waterways, in particular, determines the sensitive parts - locks, weirs, etc., that ensure the navigability of the waterways.

(3.) Rate of threat to the health and lives of humans - the health and lives of the residents and workers in the transport sector are threatened to the extent that is usual in other sectors of industry.

(4.) Rate of impact of road accidents on the environment - in particular the pollution of waterways by fuels, which adversely affects the environment and the biosphere in the water and on the banks of streams.

(5.) Rate of cost of exchange or repair - ship accident are not common, there is not usually a large extent of the damages. 


\begin{tabular}{||l|l|l|l|l|l||}
\hline Factor & $\begin{array}{l}\text { Rail } \\
\text { trans- } \\
\text { port }\end{array}$ & $\begin{array}{l}\text { Road } \\
\text { trans- } \\
\text { port }\end{array}$ & $\begin{array}{l}\text { Air } \\
\text { trans- } \\
\text { port }\end{array}$ & $\begin{array}{l}\text { Water } \\
\text { trans- } \\
\text { port }\end{array}$ & $\begin{array}{l}\text { Entire } \\
\text { trans- } \\
\text { port }\end{array}$ \\
\hline $\mathbf{1}$ & 5 & 4 & 5 & 2 & 16 \\
\hline $\mathbf{2}$ & 5 & 4 & 5 & 3 & 17 \\
\hline $\mathbf{3}$ & 4 & 3 & 4 & 3 & 14 \\
\hline $\mathbf{4}$ & 4 & 3 & 3 & 2 & 12 \\
\hline $\mathbf{5}$ & 4 & 3 & 5 & 2 & 14 \\
\hline $\mathbf{6}$ & 3 & 2 & 4 & 3 & 12 \\
\hline $\mathbf{7}$ & 5 & 5 & 4 & 1 & 15 \\
\hline $\mathbf{8}$ & 3 & 3 & 2 & 2 & 10 \\
\hline $\mathbf{9}$ & 5 & 5 & 5 & 2 & 17 \\
\hline $\mathbf{1 0}$ & 3 & 2 & 3 & 1 & 9 \\
\hline $\mathbf{1 1}$ & 3 & 2 & 3 & 1 & 9 \\
\hline $\mathbf{1 2}$ & 5 & 4 & 4 & 4 & 17 \\
\hline $\mathbf{1 3}$ & 4 & 4 & 4 & 2 & 14 \\
\hline $\mathbf{1 4}$ & 3 & 2 & 3 & 2 & 10 \\
\hline $\begin{array}{l}\text { All } \\
\text { fac- } \\
\text { tors }\end{array}$ & 56 & 46 & 54 & 30 & 186 \\
\hline
\end{tabular}

TABLE 3. Rates of criticality of the transportation infrastructure in the Czech Republic

(6.) Rate of exchange time or repair time - the ship drives are mostly repairs in the port, where the repair can be done in a short time. Repair of damage to the ship's body can usually only be performed in the dock, which prolongs the time of repair.

(7.) Rate of importance for ensuring the life-saving or emergency functions in the territory - it is needed only for the rescue work of a certain character.

(8.) Rate of importance for ensuring the functions of administration and local government - small.

(9.) Rate of importance for ensuring the functions of army and police - it is significant only in special cases.

(10.) Rate of redundancy or replacement services - water transport can be replaced by the rail or road transport.

(11.) Rate of importance for ensuring the communication functions - small.

(12.) Rate of impact of frontage failure on the economy of region (State) - water transport by its low expenses positively affects the transport of raw materials and objects of large dimensions.

(13.) Rate of importance of operability - smaller, only to a limited extent.

(14.) Rate of importance in the field of symbolic, cultural, etc. - water transport has probably the longest tradition and by this reason it is one of the symbols of the country.

The criticality rates determined by the methodological procedure described above are in Table 3

Table 3 shows that the greatest criticality has rail transport, which is followed by air transport, road transport and water transport. According to the chosen concept, the chosen scale and evaluation provided by the experts the criticality rates of both, the rail transport and the air transport are very high, the criticality rate of road traffic is high and the criticality rate of water transport is medium, and the criticality rate of whole transport system is high. From Table 3 it is clear that to the size of criticality rate mostly contributes the vulnerability to attacks, little capability of protection (the protection of long linear networks in the territory is always a big problem), the importance for ensuring the functions of the army and the police, a big impact of transport failure on the economy of region (State), and the big importance for ensuring the emergency and rescue functions in the territory.

\section{Proposals For Transport InFRASTRUCTURE SAFETy ImPROVE}

From the above analysis of transportation systems criticality it follows that the transport domain is one of the most important areas of economic and social item in the State. To its high criticality it contributes that in recent decades this fact was discovered by population groups in different States, which are not satisfied with the current state establishment in the home countries, they create their own political ideology, which most strongly criticizes the current political establishment of the State in which they live and they try to their views and goals in life violently to enforce by illegal way and as onerous procedure for the enforcement of their ideology, they consider terrorism.

Terrorism currently has a global form, so its international character leads to the need for protection against attacks. In the reference case, the facts: the great importance of transport systems, the high vulnerability of transport systems, and also the fact that part of the transportation systems can be used as an offensive weapon with great destructive potential, as shown by the attacks of 11 September 2001 in New York. It is, therefore, necessary to develop countermeasures for reducing the eventuality of attack on transportation systems and to avert the devastating impacts on the functioning the State and on the lives of citizens.

In conjunction with the results of the project the FOCUS of the European Union [15], it is necessary to consider that not only terrorism, but also a natural disasters, organizational accidents and corruption associated with the areas of control often to cause the extensive damages on the transportation systems. Preparation and production of protective measures requires substantial investment, and therefore, it is necessary to coordinate investment and to combine possible measures for protection of transportation systems against possible damages caused by disasters [16] and terrorist activities, as required by the principles of strategic management [3]. 
Due to the fact that neither terrorism nor natural disasters cannot be averted, the main goal of our activities are mitigating measures at occurrence of disasters in order to reduce the losses of human lives and minimize damages [1] 3]. Because of the importance of transportation systems is considerable, it is very urgently to implement the measures and activities that will allow the critical infrastructure elements of transportation systems effectively protect against the activities of international terrorism and other disasters. It is necessary to carry out measures that reduce the vulnerability, ensure a rapid response to the failure of critical elements, and ensure the continuity of critical elements, and on the quick recovery of the other important elements. It is necessary to:

- to estimate the vulnerability of functional elements of transportation system in the context of the assessment of transportation system objects such as bridges, tunnels, roads, highways, airports and waterways,

- to provide for the most vulnerable part of the infrastructures, the failure of which can cause the most economic damages in infrastructure up to make impossible the transport activity,

- to create scenarios of the impacts of major disasters and possible attacks, and on the basis of scenarios of impacts to determine the rapid-response procedures and the procedures for ensuring the transportation services as much as possible,

- to improve measures and activities in the areas of planning, with the aim of improving the protection against possible disasters and terrorist attacks on the transportation system, and not only from the point of view of individual systems, but in the logistics context to link measures and to increase the safety of the entire system taken in as a system of systems,

- to provide for measures that reduce the option of attack on transportation infrastructures and improve the detection of attacks on transportation infrastructure,

- to estimate the amount of investment and labour costs, which will require the implementation of mitigation measures in case of failure of transportation infrastructures and to propose a procedure for their application,

- to perform the analysis and to design the transportation infrastructure network protection against damages, which may arise as a result of possible disasters and to perform the estimation of operational inability origin as a result of their putting out of operation of functional elements or their parts,

- to reduce the frequency of interruptions of transportation systems operation as a result of a failure that cannot be reliably in advance revealed during the regular inspections.

\section{Conclusions}

The above facts show that it is urgent to pay increased attention to safety issues of transportation systems. It needs to be processed as a separate concept of transportation system safety, so the concept of critical infrastructure safety, as it shows the work [17]. From the professional point of view, it is necessary to include into safety issues solution a systemic approach, which enables us to support the technological development of transportation systems, to consider the needs of people and transportation serviceability, the environmental protection and to reduce economic damages. It is necessary to define by the expert way the issues that are necessary to solve, and to process the relevant studies in the meaning of the above recommended procedure.

\section{REFERENCES}

[1] D. Procházková. Základy řízení bezpečnosti kritické infrastruktury, 2013. ISBN 978-80-01-05245-7.

[2] D. Procházková. Bezpečnost kritické infrastruktury, 2012. ISBN 978-80-01-05103-0.

[3] D. Procházková. Strategické řízení bezpečnosti území a organizace, 2011. ISBN 978-80-01-04844-3.

[4] D. Procházková. Analýza a řízení rizik, 2011. ISBN 978-80-01-04841-2.

[5] D. Procházková. Safety of complex technological facilities, 2015. ISBN 978-3-659-74632-1, ID: 200303845.

[6] Czech Republic, Czech Code.

[7] R. L. Keeny, H. Raiffa. Decision analysis with multiple conflicting objectives, 1976.

[8] EMA. Critical Infrastructure Emergency Risk Management and Assurance [online], 2003. Www.ema.gov.au

[9] FEMA. Promoting Critical Infrastructure Protection by Emergency Managers and First Responders [online], 2005. Www.usfa.fema.gov

[10] SAIC. A Guide to Highway Vulnerability Assessment for Critical Asset Identification and Protection, 2002. National Cooperative Highway Research Program Project 20-07/Task 151B.

[11] S. (Sandia National Laboratories). Vital Area Identification, 2005. Albuquerque.

[12] US. The National Strategy for The Physical Protection of Critical Infrastructures and Key Assets, 2000.

[13] US. Guide for Critical Infrastructure Protection, 2005.

[14] Ministerstvo dopravy ČR [online]. http://www.mdcr.cz

[15] EU. FOCUS Project [online], 2012. http://www.focusproject.eu/documents/14976/ -5d763378-1198-4dc9-86ffc46959712f8a.

[16] FEMA. Guide for All-Hazard Emergency Operations Planning, 1996.

[17] US. US Critical Infrastructure Conception, 2001. 